\title{
Donald Trump, the Reality Show: Populism as Performance and Spectacle
}

\author{
Stefan L. Brandt
}

Published online: 14 April 2020

(C) The Author(s) 2020

\begin{abstract}
The rhetoric of U.S. President Trump is deeply ingrained into a populist discourse that caters to the emotional - rather than the rational - elements of human perception and interaction. Most notably, Trump's populist rhetoric is marked by links to the genre of reality television. Rather than aspiring to educate viewers, reality television emphasizes personal conflict and dramatic tension. Trump's performances (his rally speeches, but also his bestselling publications) are permeated by a realityTV aesthetics, designed to effectively entertain audiences and create an impression of authenticity. Trump's >authentic populism, < however, is also deeply embedded into the conventional structures of nationalist thought, nativism, anti-elitism, and religious fundamentalism. An investigation of Trump's populist rhetoric reveals four key components that are in tune with the key criteria that, according to Michael J. Lee, define the populist rhetoric: (1) a portrayal of >ordinary people< as heroic figures; (2) a focus on presumptive enemies as threats to traditional values; (3) attacks against an >establishment< threatening the people; and (4) an evocation of apocalyptic scenery. As a media persona, Trump combines these characteristics into a spectacle that resembles the type of entertainment program American viewers are familiar with from reality television.
\end{abstract}

Keywords Apocalypse - Anti-Elitism · Authoritarianism · Nativism · Performance $\cdot$ Populism $\cdot$ Reality TV $\cdot$ Spectacle $\cdot$ Trump $\cdot$ Trumpism

\footnotetext{
S. L. Brandt $(\square)$

Department of American Studies, Universität Graz, Graz, Austria

E-Mail: stefan.brandt@uni-graz.at
} 


\section{Donald Trump, die Reality-Show: Populismus als Performanz und Schauspiel}

Zusammenfassung Die Rhetorik von US-Präsident Trump ist tief verwurzelt in einem populistischen Diskurs, der eher die emotionalen als die rationalen Elemente der menschlichen Wahrnehmung und Interaktion anspricht. Vor allem Trumps populistische Rhetorik lehnt sich an das Genre des Reality-TV an. Reality-TV ist nicht bestrebt, das Publikum zu erziehen, sondern es zu unterhalten, wobei es persönliche Konflikte und dramatische Spannung betont. Trumps Performances (seine Kampagnenauftritte, aber auch seine Bestseller-Publikationen) sind von einer Reality-TVÄsthetik durchdrungen, die das Publikum effektiv unterhalten und einen Eindruck von >Authentizität $<$ hinterlassen soll. Trumps >authentischer Populismus $<$ ist jedoch auch in die konventionellen Strukturen von Nativismus, Anti-Elitismus, dualistischem Denken und religiösem Fundamentalismus eingebettet. Eine Untersuchung von Trumps Populismus offenbart vier Schlüsselkomponenten, die im Einklang mit den Schlüsselkriterien stehen, die laut Michael J. Lee die populistische Rhetorik definieren: (1) eine Darstellung von >einfachen Leuten< als Heldenfiguren; (2) Konzentration auf mutmaßliche Feinde als Bedrohung traditioneller Werte; (3) Angriffe gegen das >Establishment<, das angeblich das Volk bedroht; und (4) Bezüge auf apokalyptische Szenarien. Als Medienpersönlichkeit kombiniert Trump diese Komponenten zu einem Spektakel, das der Art von Unterhaltungssendung ähnelt, welche das amerikanische Publikum bereits aus dem Genre des Reality-TV kennt.

Schlüsselwörter Apokalypse - Anti-Elitismus - Autoritarismus · Nativismus · Performance $\cdot$ Populismus $\cdot$ Reality TV $\cdot$ Spektakel $\cdot$ Trump $\cdot$ Trumpism

\section{Introduction - Populism in the Age of the Spectacle}

Since the U.S. presidential election of 2016 - and especially after Donald Trump's spectacular victory over Hillary Clinton - populism seems to have resurfaced as a battle cry in the political arena. »Three years into the Trump era, « The Washington Post wrote in a recent article, $\gg$ the $>p$-word $<$ is seemingly everywhere « (Cantrell 2019). For many decades, or so it seemed, the $>p$-word, $<$ populism that is, had been no more than a footnote in American history, to be mentioned - if at all - in the context of the American 1890s and William Jennings Bryan's unsuccessful bid for

\footnotetext{
${ }^{1}$ Making a Nation, a comprehensive history of the United States and its people, contains all but three slim columns on »The Rise of Populists « in the late $19^{\text {th }}$ century and the emergence of the short-lived People's Party, not mentioning any other instances of populism in U.S. history (Boydston/Cullather/Lewis et al. 2002, pp. 563-564). In some accounts, Andrew Jackson, U.S. President from 1829 to 1837, is described as an early populist, with regard to his concept of >the people< as America's secret and forgotten heroes. Since Jackson was equally a staunch defender of slavery, Jacobson and Waychoff (2017) call his policies »a strange kind of populism. « According to Michael Kazin (2016), the term >populist< disappeared in the 1950 s as a result of McCarthyism. Since the 1960s, the term has occasionally been used for a number of politicians, from George Wallace and Ronald Reagan to George McGovern, Ralph Nader, and even Obama (cf. Kazin 2016).
} 
the presidency. ${ }^{1}$ The Trump Era, with all its ramifications in social and cultural practice, has catapulted the $>p$-word $<$ back into the public consciousness. Since then, numerous articles and academic essays have appeared that classify Trump's campaign and presidency as populist (cf. Gusterson 2017; Inglehart/Norris 2016; Kazin 2017, pp. 75-86).

But is the concept of >populism < really so easy to use as a label for politicians such as Trump? Is it as stable and coherent as many reviewers seem to think? Or is it not rather fluid in its applicability to politicians on both sides of the aisle? ${ }^{2}$ In the current U.S. presidential campaign for the election in 2020, Democratic hopeful Pete Buttigieg has cast doubt on the clarity of the term >populism<: »I think that's maybe the most slippery term of all, « he told BuzzFeed News in a recent interview, »I think anyone who wants to win an election is trying to be popular. I guess my anxiety with populism is ... [that] it misstates the balance between following the people and leading the people« (qtd. in: Gomez 2019).

Buttigieg's discussion of populism as a concept potentially operating according to the regularities of economic exchange (>following/pleasing the people $<$ ) leads us to the realm of television, which equally functions in terms of popularity and effect (cost-utility value, ratings, etc.). What makes Trump's populism so effective (and so explosive, for that matter) is that it employs established parameters from a variety of mass communication forms - in particular, the genre of reality television ${ }^{3}$ (next to components of the stand-up comedy and the sitcom). A highly popular genre, reality TV (famous through shows such as Big Brother, American Idol, and The People's Court) is characterized by the seemingly improvised and unscripted presentation of real-life situations. Reality television distinguishes itself from the documentary genre by its focus on drama and emotions. Rather than aspiring to educate viewers, reality television emphasizes personal conflict and dramatic tension. Using its aesthetic and cultural influence to create an effect of cogency, reality TV relies upon unarranged settings and a sense of irreverence towards established traditions - a trajectory that goes along with Donald Trump's claims to >tell it as it is < and his reputation to engage in heated conversations, as demonstrated in the televised 2016 debates with his competitors Marco Rubio and Ted Cruz (cf. Krause-Jensen/Martin 2018, p. 108).

In my essay, I want to show that Trump's populism is deeply entrenched into the world of the media, strategically employing some of the key strategies and aesthetic techniques established in this segment of public discourse. The discourse of Trumpism is essentially performative in that it aims at >events $<$ and $>$ staging $<$ as modes of representation (cf. Attridge 2004, pp. 133-140; Bessire/Bond/Holman/

\footnotetext{
2 Michael Kazin calls Donald Trump »an unlikely populist « whose agenda does not fit into the typical model, given his own personal background. »The Republican president inherited a fortune, boasts about his wealth and his many properties, shuttles between his exclusive resorts and luxury hotels, and has adopted an economic plan that would, among other things, slash tax rates for rich people like himself« (Kazin 2017, p. 75).

3 Due to its focus on purportedly unscripted situations from real life, reality television claims a high sense of accuracy and naturalness. »Reality $\mathrm{TV}$, Su Holmes and Deborah Jermyn point out, »has [...] come to occupy a place at the forefront of contemporary television culture - a position from which it seems to sspeak < particularly clearly to the ways in which broadcasters are seeking to attract audiences in the multichannel landscape« (Holmes/Jermyn 2004, p. 1).
} 
Eggert 2017). ${ }^{4}$ Like the popular media themselves, which are meant to entertain audiences and satisfy a market, Trump's performances are designed to sell something. Thus conceived, they can be understood in terms of what Michael Halliday (1978, p. 92) calls »communicative competence « - an ability grounded in a series of performative acts to convey messages and emotions as effectively as possible. In my reading, this type of performance resembles what Guy Debord (1997) has described as >spectacle. $<$ Writing in 1967, Debord defines spectacle as a key force of modern societies in which the representation has replaced lived social practice. The spectacle, Debord writes, »is the very heart of society's real unreality (Debord 1997, p. 13). ${ }^{5}$ It determines the exchange value of all things in society. »Understood on its own terms, the spectacle proclaims the predominance of appearances and asserts that all human life [...] is mere appearance« (Debord 1997, p. 14). With his 2016 presidential campaign, Donald Trump has cultivated this celebration of appearances, showing himself as »the master of media spectacle« (Kellner 2016, p. 1).

The spectacle character of Trump's rhetoric becomes obvious in the show-like dimension of his rallies and writings which emphasize performance over factuality. One example is Trump's now famous feud with Arnold Schwarzenegger, during which the president mocked the actor for his poor ratings as the host of the TV show The Apprentice. Asked about his successor's performance in the iconic show, Trump stated: »Arnold Schwarzenegger ... You know what? He died ... I was there« (qtd. in: Boucher 2019). Trump's attack seems even more remarkable when one considers the president's own background in the entertainment industry. A billionaire and real estate tycoon, Trump was the owner of the >Miss USA< beauty pageant from 1996 to 2015 , which underscored his reputation as a ladies' man. Already a well-known figure on U.S. television and cinema (starring, among other roles, in an episode of the HBO series Sex and the City and the Hollywood blockbuster Home Alone 2: Lost in New York), his path to celebrity stardom was finalized when he became the coproducer and star of the reality TV series The Apprentice (NBC 2015), a program in which a group of successful entrepreneurs judges the business skills of various contestants. Trump's words »You're fired!« by which each episode was ended (at once the moment when one of the contestants was eliminated from the race) soon became the show's tagline and Trump's personal catchphrase. »Trump's rise to global celebrity and now political power, « Douglas Kellner states, »is bound up with his use of media spectacle « (Kellner 2016, p. 1). ${ }^{6}$

When Trump's presidential campaign was officially started on June 16, 2015, at Trump Tower in New York City, most observers were not too surprised to see the business mogul run for the highest office in the country - especially after his potential bid for the presidency had been a persistent rumor launched in venues

\footnotetext{
${ }^{4}$ In my usage of the term >performance, $<$ I follow Halliday's (1978) and Attridge's (2004) approach rather than that developed by Chomsky (1965) who sees >performance< in opposition to >competence< (along the lines of de Saussure's separation between parole and langue).

5 For Debord (1997, p. 12), »[t]he whole life of those societies in which modern conditions of production prevail presents itself as an immense accumulation of spectacles. All that once was directly lived has become mere representation.«

${ }^{6}$ For a discussion of the >media spectacle < in political discourse, see Kellner $(2001 ; 2003)$.
} 
such as the talk radio program The Howard Stern Show and the animated sitcom The Simpsons. Trump's reputation as a passionate, hard-boiled businessman first benefited his campaign, but later became a liability when his seemingly >unhinged< way of leading the White House was seen more critically. In Michael Wolff's 2018 infamous book Fire and Fury: Inside the Trump White House, this sense of emotional exceptionalism apparently accompanying the Trump presidency is highlighted in a spectacular fashion. Taken from Trump's own remarks regarding the conflict with North Korea, the biblical phrase »fire and fury « seems also a suitable description of the populist dimension of the Trump rhetoric, its catering to apocalyptic scenarios (with respect to world politics and the state of the union) as well as to dramatic effects that demand the audience's unrestricted attention. What the >fire and fury< episode shows, is that Trump uses the spectacle to create the widest possible public response and energize his following.

An investigation of Trump's populism reveals four key components which are in tune with the »four interrelated and mutually reinforcing themes « that define the populist rhetoric according to Michael J. Lee: (1) a portrayal of ordinary people as »heroic defenders of >traditional< values «; (2) a focus on presumptive enemies as threats to these values (often »different « in terms of »race, class, or geographic location «); (3) the characterization of a type of government that threatens the people; and (4) an evocation of »apocalyptic confrontation « to reach »revolutionary change « (Lee 2006, pp. 358-62). As I will outline in this essay, all four features can be found in Trump's performances during the campaign and his presidency. The transformation of the billionaire Trump into a populist is not without irony, since Trump's personal background seems to defy the very paradigms of his own populism. While traditional populists in the mold of William Jennings Bryan ostentatiously fought against banks and >money power $<$ Donald Trump became known precisely as part of the monopolies that populism used to oppose. What's more, Trump himself fits the stereotypical description of the »haughty financier« and »stout industrialist top hat on his fleshy head and diamond stickpin gleaming from his silk tie« (Kazin 1998, p. 1; cf. Lee 2006, p. 373). Against conventional class divisions, the New York billionaire has managed to evoke the impression with audiences and voters that he is an honest and authentic advocate of the rights of common people. Michael Kazin explains this seeming incongruity as follows: »A politician does not have to live among people of modest means, or even tout policies that would boost their incomes, to articulate their grievances and gain their support. In 2016 Trump clearly tapped into a deep vein of distress and resentment among millions of white workingand middle-class Americans « (Kazin 2017, p. 75).

Notably, this rhetorical flexibility ${ }^{7}$ across the lines of class has strengthened Trump's reputation as an independent, incorruptible fighter. Having associated him-

\footnotetext{
7 Michael Wolff comments on this seeming contradiction as follows: »The paradox of the Trump presidency was that it was both the most ideologically driven and the least. It represented a deeply structural assault on liberal values [...]. But from the start it also was apparent that the Trump administration could just as easily turn into a country club Republican or a Wall Street Democratic regime« (Wolff 2018, p. 177).
} 
self in the past with different political agendas ${ }^{8}$, Trump endorses a kind of populism that, indeed, has no »fixed meaning or ideology« (Rolfe 2016, p. 24; cf. Woodward 1983, p. 57). Trump's populism is, to use Michael Kazin's terminology, an extremely »elastic« and »flexible mode of persuasion« (Kazin 1998, p. 3) - one that works especially well in the realm of mainstream television. Being an avid user of Twitter, Trump reaches his audiences through a mixture of populist rhetoric and mass entertainment (see Ott 2017, pp. 59-68). Employing the popular mechanisms of television (and especially that of the reality-TV genre), the Trump discourse gives consumers (and even those who criticize Trump) the drama and excitement that the digital age embraces - encapsulated in furious twitter raids, emotional attacks against presumptive enemies of the state, and spectacular >live< events viewers are familiar with from reality soap shows. This populist spectacle includes both his assistants in the present and in the past, Ivanka Trump, Steve Bannon, and >Omarosa< Manigault, all of whom participate in this type of $>$ reality show ${ }^{9}$, and the persona of Trump himself who continuously stages himself in public.

As I will argue in what follows, Lee's categories of classic populism apply to Trump's elastic and apparently >un-ideological< self-representations. Conforming to some of the established formulas of the populist rhetoric, Trumpism seems equally capable of adapting to the mechanisms and affordances of media society, garnering support among wide segments of the population. The Trumpist rhetoric may seem outdated and even obsolete in its references to traditional elements of populism (especially in its employment of >us vs. them < patterns and its catering to a 19th-century type of savior imagery); however, its techniques of reactivating these components and harnessing them to meet the necessities of the digital age deserve attention.

\section{Nationalist Thinking and the Vindication of >Ordinary People<}

The first marker of populism, according to Lee (2006, p. 358), is the construction of »a stable and definable >people $<[. .$.$] as defenders of >traditional < values. « In the pop-$ ulist rhetoric, >the people< are stylized into »ordinary, simple, honest, hard-working, God-fearing, and patriotic Americans « (Lee 2006, p. 358). Populist voices, Michael Kazin holds, often »conceive of ordinary people as a noble assemblage « (Kazin 1998, p. 1). Since, in this narrative, the >nobility of these presumptively maltreated citizens is not recognized by the media and mainstream cultural practice, it takes a >hero in shining armor who will come to their rescue and grant them the justice they deserve. Trump has repeatedly embarked on this traditional tale of vindication.

\footnotetext{
8 Trump was officially affiliated with the Republican Party from 1987 to 1999, was a registered Democrat from 2001 to 2009, then again as a Republican from 2009 to 2011, before signing up as an Independent between 2011 and 2012. Since 2012, Trump once again has been affiliated with the Republican Party.

${ }^{9}$ Omarosa Onee Manigault Newman, known simply as $>$ Omarosa, $<$ was already a television celebrity before Trump hired her as Director of Communications in the White House. Having been a contestant on the first season of Trump's show The Apprentice in 2004, Omarosa has become a flamboyant reality-TV star. After her resignation from the White House, she appeared on the first season of Celebrity Big Brother in 2017 and published a scandalous book about Trump and his administration titled Unhinged (Newman Omarosa 2018).
} 
As in classical populism of the 1890s and 1900s, Trumpism fashions itself around a powerful warrior figure who knows how »to fix it« (Trump 2016a, p. 83; cf. Chicago Tribune 2016). Only this fearless hero can defend the >traditional values of the >common man.< It is the ordinary American, the hard-working citizen who has been ignored for too long whose rights will finally be cherished and reinstated. ${ }^{10}$

The symbolic construction of $>$ common people $<$ in the populist rhetoric goes hand in hand with nationalist thinking. Like >the people, $<$ the image of the $>$ strong nation $<$ is designed as a consoling fantasy meant to conjure up the vision of a national community that bestows togetherness and unity upon its citizens. »From this day forward, « Trump exclaimed in his inauguration speech on January 20th, 2017, »a new vision will govern our land. From this day forward, it's going to be only America first. America first « (Trump 2017a). The fate of the >people, $<$ it seems, is intimately conjoined with that of the nation: »January 20, 2017, will be remembered as the day the people became the rulers of this nation again « (Trump 2017a). Trump's rhetoric takes its energy from the specific political discourse of the election year.

When Hillary Clinton, in an LGBT campaign fundraising event in New York City, described »half of « Trump's supporters as belonging to a »basket of deplorables« (CBS News 2016), the phrase was immediately taken up by Breitbart and other Trump-friendly media. Had Trump's opponent just discredited a whole segment of the American people as inferior? Clinton's words eventually became one of the nails in the coffin of her presidential campaign, endowing Trump voters with a sense of pride in their social class. Trump also took up the phrase, turning it into a badge of honor for his supporters and scolding his opponent for her hostile language. ${ }^{11}$

The narrative of a >vindication of common people< lies at the heart of Trump's nationalist agenda. »Together we will make America strong again, « he proclaimed in his inauguration speech, »We will make America wealthy again. We will make America proud again. We will make America safe again. And, yes, together, we will make America great again« (Trump 2017a). Trump's campaign slogan »Make America Great Again (MAGA) « is echoed here in a series of anaphoric statements meant to hammer in the notion of >greatness $<$ of the American nation. Combined with the repeated usage of the $>$ we, $<$ a vision of unity and strength is conveyed. ${ }^{12}$

\footnotetext{
10 The first U.S. president who modeled himself as a defender of the >common man< was the Democrat Andrew Jackson, a wealthy slave owner who fought in the War of 1812 against the British and prided himself on having the stubborn nature of a >jackass< (an aphorism which earned the Democrats its association with the donkey, which is still the party mascot today). Jackson's anti-elitist stance culminated in his inauguration on March 4, 1829, with thousands of people from all classes celebrating in what historian Edwin A. Miles describes as »[s]heer bedlam« (Miles 1978, p. 305). Joseph Story, a Justice of the U.S. Supreme Court, who absconded from the scene in obvious disgust, later wrote that he »never saw such a mixture. [...] The reign of King >Mob< seemed triumphant« (qtd. in: Miles 1978, p. 305). Notably, Trump has repeatedly invoked and lauded President Jackson, even pitting a portrait of him in the Oval Office. This adoration makes Trump, in the words of J.M. Opal, »the first president to so openly admire and point to Jackson as a model, and to borrow so clearly and explicitly from the language of Jacksonian >democracy « (qtd. in: Jacobson/Waychoff 2017).

${ }^{11}$ In the weeks before the 2016 election, $t$-shirts, manufactured by Trump supporters, with slogans such as »Basket of Deplorables « and »Gun Toting Deplorable Christian Women Vote Trump« appeared (see Potter 2016).

12 »Let's Make America Great Again« was first used as a slogan in Ronald Reagan's 1980 presidential campaign. After Trump's election campaign was officially launched in July 2015, the patriotic catchphrase
} 
It is no coincidence that this rhetoric often references sports events (and the discourse of entertainment in general), as in the first chapter of Trump's campaign book, suggestively titled »Winning Again« (Trump 2016a, p. 1). Throughout the book, Trump connects nationalist thinking to the motif of winning, often engaging in superlatives to make his point: »We are unique among the nations of the world, and we should be leading, not following. Winning, not losing. [...] America is the greatest country that has ever existed on the Earth, and yet for some reason our leaders are reluctant to press our advantage« (Trump 2016a, p. 136). Nowhere does Trump's endorsement of American exceptionalism become as obvious as in his campaign motto »America First «; the slogan highlights the competitive spirit of his campaign and of Americanness per se, evoking a rhetoric which elevates the nation to a pinnacle of progress and the individual to its chief protagonist. ${ }^{13}$

The junction of patriotic imagery and a celebration of >common people $<$ is especially present in ceremonies held in honor of fallen soldiers. Here, the nation is able to commemorate its own past and elevate itself on behalf of those who have sacrificed their own lives for the country. One such moment of cultural elevation occurred during Trump's speech at a Joint Session of Congress on February 27, 2017 when the U.S. President talked about Ryan Owens, a U.S. Navy Seal who died in Yemen during a military operation. This incident was later described by one commentator as the moment Trump »became President of the United States. Period « (Van Jones qtd. in: Kurtz 2017). In the midst of his speech, Trump suddenly addressed the soldier's wife in the audience: »Ryan died as he lived - a warrior, a hero, battling against terrorism, and securing our nation « (Trump 2017b, 0:43-0:51). After frenetic applause and accompanied by images of the mourning widow struggling with tears, Trump added even more pathos: »Ryan's legacy is etched into eternity« (Trump 2017b, 1:41-1:45).

In a YouTube clip which soon went viral, the dramaturgy of the event is effectively caught on camera in a series of close-ups. Not only are we left with Trump's bombastic statement of the soldier's legacy being »etched into eternity.« The camera further transports us into what seems to be an emotional hurricane, showing us, after a zoom, the devastated wife's outburst of tears. ${ }^{14}$ The performance of Trump's speech seems replaced by the even more powerful performance of images, of a grieving widow, of hands and gazes directed upwards. To what degree this is a joint performance of Trump, the camera and the other protagonists becomes obvious in the final moments of the scene (which were aired in full length on FOX). After the camera has shown the grieving widow for more than $90 \mathrm{~s}$ in one shot (longer than Trump before) and after the applause has abated, we suddenly hear Trump picking up on

became its registered trademark. In contrast to its use in Reagan's 1980 campaign, the motto now assumed an increasingly nativist and anti-immigrant tenor (cf. Kellner 2016, p. 26; Morgan 2019, pp. 59-62).

13 The slogan »America First« was first used by U.S. President Woodrow Wilson in 1916. In the midst of World War I, »America First « was meant as an anti-expansionist message to keep America away from the war. During the 1920s, »America First« was also used as a slogan at rallies held by the Ku Klux Klan (»America First - One God. One Country. One Flag«) to convey the Klan’s message of white superiority (Emery 2018).

14 The applause and the encouraging gestures of the other participants, among them Ivanka Trump, reinforce this effect (Trump 2017b). 
the emotional quality of the moment: »And Ryan is looking down, right now, you know that, and he's very happy, because I think he just broke a record « (Trump 2017b, 3:28-3:36).

This is the moment when the event, which already featured many liturgical aspects, fully transforms into a religious ceremony. The widow looks up as if to communicate with her deceased husband. And Trump complements this performance by invoking the perspective of the fallen soldier. Significantly, the motif of >winning < is even present in this unlikely context (»I think he just broke a record «). The dramaturgy - and liturgy - of this moment is representative of a whole series of performances by U.S. President Donald Trump in which emotional images (such as that of the dead soldier hero) are employed to evoke a state of emotional turmoil and excitement. At the same time, the scene reminds audiences of speeches by televangelists such as Billy Graham, Pat Robertson, and Joyce Myers; all of these often invoke the Heavenly Father through ostentatious gestures towards the sky (cf. Griswold 2016). ${ }^{15}$

In the populist rhetoric, the glorification of >national heroes< (like Ryan Owens) is rooted in a kind of leader cult. Accordingly, the >people< can only be rescued by a messiah figure who will guide them out of misery and into a bright future. In this playbook, Trump became, in Michael Wolff's words, »the ultimate avatar of Fox's angry common man« (Wolff 2018, p. 3). It is almost uncanny to see how much of this trajectory was anticipated in Trump's own campaign book Great Again: How to Fix Our Crippled America. In the book, Trump makes the point that the search »to find the best people « to govern a country should generate a strong, authorial figure - a person that, in all his negotiation skills, yet steadfastness, resembles Trump himself: »A great leader has to be flexible, holding his ground on the major principles but finding room for compromises that can bring the people together. A great leader has to be savvy at negotiations so we don't drown every bill in pork barrel bridges to nowhere (Trump 2016a, p. 96).

The anaphoric use of the term great leader is combined in this passage with a call to bring »the people« together (presumably under this leader). In American Nightmare, Douglas Kellner has called the cult surrounding Trump an »authoritarian populism « (Kellner 2016, pp. 19-20) that draws on Manichean thinking to maintain hierarchical orders within society. ${ }^{16}$ The following two sections will deal with the function of specters (the >enemy outside < as well as the >enemy within $<$ ) in Trump's rhetoric to produce a fervent national identity.

\footnotetext{
15 A good case in point is the TV show Jack Van Impe Presents, aired weekly on God TV, which comments on the news through the lens of the bible. Van Impe, who ferociously supported Trump in the 2016 U.S. election, implored his viewers on November 3 (only five days before the election) to »pray « for Trump. While articulating his election manifesto for Trump, he raised both fists to heaven in a dramatic gesture (God TV 2016, 4:49-4:54). During his victory speech in the early morning of Nov. 9, 2016, Trump made a similar gesture to the sky when he invoked his deceased parents (Trump 2016c).

16 Snyder goes as far as to label Trump a »sadopopulist, whose policies were designed to hurt the most vulnerable part of his electorate « (Snyder 2018, p. 272). In Snyder's words, »[t]he electoral logic of sadopopulism is to limit the vote to those who benefit from inequality and to those who like pain, and take the vote away from those who expect government to endorse equality and reform« (Snyder 2018, p. 274).
} 


\section{Nativism and the Populist Construction of Enemy Figures}

Populism's emphasis on $>$ the people $<$ is closely tied to the construction of threatening enemy figures. Such >enemies of the state, $<$ the populist rhetoric suggests, pose an omnipresent threat to society that must be countered by the >people. $<»$ The >people's collective fantasy, « Lee states, »is a narrative of unseating an enemy that has an unyielding commitment to hoarding power and to the destruction of >traditional< values « (Lee 2006, p. 359). With the rise of the populist Tea Party after 2009, anti-foreign sentiments resurfaced in U.S. politics - a phenomenon that some had believed to have disappeared in the > post-race < years of the Obama Era. ${ }^{17}$ Around the same time, the so-called >birther movement< gained momentum which questioned that President Obama was a natural-born citizen of the United States (cf. Bond/ Homan/Eggert, 2017, p. 670).

With Trump entering the political arena in 2015, various populist discourses converged that had built up during the Obama years. This included elements of nativism (that is, the policy of > safeguarding < the interests of the native population against those of immigrants). ${ }^{18}$ In the announcement of his presidential bid in 2015 , Trump already tinted his political agenda with what was later perceived to be antiimmigrant sentiment. Notably, one of the first sections of the speech (right after ISIS and a trade deal with China) concerned the Mexican-American border: »When Mexico sends its people, they're not sending their best. [...] They're sending people that have lots of problems, and they're bringing those problems with us. They're bringing drugs. They're bringing crime. They're rapists. And some, I assume, are good people « (Trump 2015). ${ }^{19}$ Trump's references to a broad nativist sentiment were not coincidental. In a way, they struck a chord in a cultural climate that began to become more and more skeptical of global and local changes. In the election year of

\footnotetext{
17 While at first organized as a libertarian and fiscally conservative grassroots movement, the >Tea Party< protests soon transformed into a channel for »passionate populist enthusiasm from right-wing GOP voters « (Skocpol/Williamson 2013, p. 164). According to Rick Klein, the Tea Party movement released a kind of »populist anger« that had to be taken seriously as a cultural phenomenon (qtd. in: Skocpol/Williamson 2013, p. 140).

18 Nativism has repeatedly surged during specific nodal points of U.S. American history. In the 1840 s, prejudice against immigrants led to a major anti-immigrant movement, which culminated in the foundation of $>$ The American Party< in 1849. In public announcements, native-born Americans were warned to »beware of foreign influence« (Reddit 2019). Membership was limited to white Protestant males. Commonly known as $>$ the Know-Nothings, $<$ the party won seats in Congress in 1854 and had a prominent supporter with U.S. President Millard Fillmore from the Whig Party. Towards the end of the century, widespread xenophobia led to the Chinese Exclusion Act of 1882 and the founding of the American Protective Association in 1887 , a secret society with 500,000 members and the declared goal to stop immigration. Trump's usage of nativist rhetoric and his pressing for a border wall must be seen against the historical backdrop of these anti-immigrant movements (see Elving 2019).

19 In Great Again, Trump claims to have been misunderstood by the media who allegedly used the segment from his speech since »[i]t gave them some headlines« (Trump 2016a, p. 14). »The next thing you heard was that Trump said all immigrants were criminals. That wasn't what I said at all [...]. What I said was that among all the illegal immigrants coming from Mexico were some pretty bad people, some of them are rapists, some of them are drug dealers, some of them are coming here to live off the system, and we'd better take immediate and tough measures to close our borders to >illegals« (Trump 2016a, p. 14). For a discussion of the >racializing < aspects of Trump's >bad hombres< speech (as it was often termed later), see Hughey (2017, pp. 127-129).
} 
2016, the stage was set for such fearful voices to be articulated and heard. Michael Wolff describes this specific historical situation as follows: »Everywhere there was a sudden sense of global self-doubt. Brexit in the UK, waves of immigrants arriving on Europe's angry shores, the disenfranchisement of the workingman, the specter of more financial meltdown [...] - everywhere was backlash. [...] Did Trump get where history had put him? (Wolff 2018, pp. 5-6). Fanned by the >alt-right< movement, the Trump discourse was able to capitalize upon nativist impulses, transforming what until then had been a vague atmosphere or mood into a viral zeitgeist. The populist recurrence of nativism in the Trump Era is based in a number of social and psychological factors that influenced voter behavior and gave the tone in public discourse a decisively anti-immigrant (and anti-refugee) pitch.

A key component of the nativist rhetoric is fear - fear of the >other, <fear of the unknown, fear of an uncertain future. The journalist Bob Woodward has analyzed >fear< as one of the driving forces behind Trump's performance in the White House. In Fear: Trump in the White House, he writes: »Real power is fear. It's all about strength. Never show weakness. You've always got to be strong. Don't be bullied. There is no choice« (Woodward 2019, p. 175). Woodward's analysis looks at the dominant power structures and hierarchies in U.S. political practice (>real power is fear $<$ ) that made a Trump victory in 2016 possible. If the American way of life is really »under assault, « as Trump has repeatedly claimed in his speeches and writings (Trump qtd. in: Associated Press 2019), the government (and, by implication, >the nation $<$ ) has to defend itself, in this view, against such threats. In the age of globalization and economic change especially for the American working class, multiple challenges (such as automation) arise in which different groups can be effectively played out against one another. »Rather than face those difficulties and uncertainties, people who sense their living standard declining can instead grasp after villains, and a fantasy takes shape: if $>$ we $<$ can somehow keep $>$ them $<$ out (build a wall) or keep them in >their place< (in subservient positions), > we < can regain our pride « (Nussbaum 2018, p. 2). ${ }^{20}$

Fear is also one of the key factors behind the divisiveness that permeates much of the current political and social climate in the United States. The populist rhetoric often aims at firing up such worries and anxieties, creating a scenario in which some groups are allowed to feel connected in their common angst, while other groups are symbolically excluded. Following Guy Debord, this is one of the characteristic aspects of the spectacle, which »unites what is separate, but [...] unites it only in its separateness « (Debord 1997, p. 22). For Debord, the divisive nature of the spectacle is simultaneously a marker of modernity and its medial apparatuses: »Like modern society itself, the spectacle is at once united and divided. In both, unity is grounded in a split. As it emerges in the spectacle [...], this contradiction is itself contradicted

\footnotetext{
20 The philosopher Martha C. Nussbaum sees the motif of >envy< as a key trigger for what she calls, in her book title, The Monarchy of Fear. »[E]nvy is born of insecurity. Fear, then, is at its root: the fear of not having what one desperately needs to have (Nussbaum 2018, p. 140). Another connected sensation, jealousy often motivates the rhetoric of fear, being grounded in the »fear of losing something one has « (Nussbaum 2018, p. 139).
} 
by virtue of a reversal of its meaning: division is presented as unity, and unity as division« (Debord 1997, p. 36).

Debord's observations regarding the spectacle character of modern society remind us of the current paradigm shift under Trump regarding the relation between the government and the media. Amongst accusations of >fake news< and invocations of >alternative facts, $<$ the fault lines within U.S. society have apparently intensified, giving rise to »regular, uncontrolled bursts of anger and spleen« on the part of the Trump administration and its executive in chief (Wolff 2018, p. 48). In the following section, I will continue my discussion of Trump's enemy rhetoric to include the >establishment< as a key figure, upon which populist fears can be projected.

\section{Anti-Establishment Rhetoric}

The creation of enemy figures is closely linked to a rejection of what is regarded as the $>$ system $<$ (or in some populist excesses, the >Deep State $<$ ). ${ }^{21} \gg$ The $>$ system $<$, « Michael J. Lee explains »is an amalgamation of numerous sites within the national political and economic order in which power is distributed, governed, and managed. As defined by populists, the >system< once represented the Founders' conception of pure justice« (Lee 2006, p. 360). In his inauguration speech, President Trump recurred to this narrative when he dramatically announced that »we are transferring power from Washington DC and giving it back to you, the people. For too long, a small group in our nation's capital has reaped the rewards of government while the people have borne the cost. Washington flourished - but the people did not share in its wealth« (Trump 2017a).

This bombastic gesture clearly aimed at both former President Obama, who was sitting in the audience during the speech, and at the >elite< of Washington politicians who had supposedly gotten rich at the expense of $>$ the people. $<$ In his rhetoric, Trump positions himself - ironically enough - as an >anti-establishment< president; he channels a fundamental anger against >those in Washington $<$ who seemingly advocate their own interests and not those of >the people.< Notably, »Drain the Swamp! «was one of Trump's most effective slogans during his presidential campaign. In The Road to Unfreedom, Timothy Snyder sketches a long history of cases in which Trump built his rhetoric upon a logic of slandering enemies from the political establishment:

Trump was the first presidential candidate to say that he would reject the vote tally if he did not win the election, the first in more than a hundred years to

\footnotetext{
21 Theories on the > Deep State< usually suggest that a secret conglomeration consisting of the Washington government, the CIA, the NSA, the FBI, and other state-sponsored institutions (sometimes the illuminati or Google) conspire against the >American people< to maintain group benefits and further economic profits at Wall Street (see Scott 2015). In a cartoon by American satirist Ben Garrison, a self-declared libertarian whose comic strips have been widely distributed by the alt-right, portrays Trump in the midst of a swamp that he is trying to drain. Equipped with a truck named »Swamp Draining Service, « Trump faces a monster reminiscent of the iconic >creature from the black lagoon, < accompanied by representatives of the >Washington Elite, < that asks him: »What the Hell Do You Think You're Doing?«(Garrison 2017). Typically, the $>$ Deep State $<$ is represented as a »hydra « with many heads that violently battles against its disempowerment (cf. Tracy 2018).
} 
urge his followers to physically beat his opponent, the first to suggest (twice) that his opponent should be murdered, the first to suggest as a major campaign theme that his opponent should be imprisoned. (Snyder 2018, p. 274)

At the same time, Trump's performances highly depend on the staging of his personal enemies as enemies of the American nation - above all, »Crooked Hillary, « the >cut-throat career woman< who seemingly engaged in criminal activities, »Lyin' Ted« (for Ted Cruz), »Little Marco« (for Marco Rubio), and so on (see Bond/ Holman/Eggert, 2017, p. 668). The defamatory nicknames Trump has invented for his enemies (all of which accentuate their difference from the >common American $\operatorname{man}<$ ) are as legendary as effective (cf. Pelled/Lukito/Boehm et al. 2019, pp. $176 \mathrm{ff}$.). In a particularly hostile tweet against his opponent Hillary Clinton, Trump stated, just a few weeks before the 2016 election: »Hillary Clinton should have been prosecuted and should be in jail. Instead she is running for president in what looks like a rigged election « (Trump 2016b). In this tweet, Trump combines a ferocious attack against Clinton with his previously made claim that the election (the outcome of which seemed to be in his opponent's favor) was manipulated. The tweet uses a >dog-whistle< type of communication, by which viral conspiracy theories regarding his rival's alleged criminality and a presumptive partiality of the mainstream media (including election polls) are effectively employed. By means of stigmatization, Clinton becomes the epitome of a >dishonest political elite $<$ that should be undermined and removed. By launching such radical moves against his political foes, Trump stylizes himself into a representative of »an insurgency movement on behalf of ordinary Americans disgusted with the corrupt establishment, incompetent politicians, [...] and politically correct liberals « (Inglehart/Norris 2016, p. 5). ${ }^{22}$ Defamations of the >government elite < as corrupt or even criminal are a vital part of the strategy of the populist rhetoric; at the same time, they stand in a long tradition of anti-establishment speech, in which >those in Washington< are accused of acting only in their own interest, but not in that of >the people< (cf. Lee 2006, p. 375).

\section{Apocalyptic Imagery}

In the populist rhetoric, the battle against the $>$ system $<$ assumes a distinctly apocalyptic dimension. The only force that can stop the decline of society and its inner destruction by enemies from within and from outside is a fundamental change of the status quo. »[A]pocalyptic confrontation, «Lee writes, »is presented as the vehicle to revolutionary change. If the system rhetorically accelerates the populist crisis, apocalyptic confrontation is its boiling point, a zero-sum portrayal of a mythic battle (Lee 2006, p. 362). The current political climate, it seems, has encouraged a con-

\footnotetext{
22 One of the key scenes of the second debate between the party candidates on October 9, 2016, was an exchange of words, in which Clinton contended »It's just awfully good that someone with the temperament of Donald Trump is not in charge of the law in our country, « upon which Trump snapped back at her »Because you'd be in jail « (see Wilkinson et al. 2016). The fact that Trump promised on national television that he would use the authority of the presidential office to persecute his political rival showcased the degree of divisiveness that had permeated the political discourse in the election year.
} 
frontational discourse that tends to dramatize and employ apocalyptic scare rhetoric rather than look at the facts objectively. ${ }^{23}$

In his writings and speeches, Trump tactically conjoins nationalistic impulses ${ }^{24}$ with apocalyptic imagery. Thus, he starts Great Again with the lines, »America needs to start winning again « (Trump 2016a, 1). As if to highlight the sports metaphor behind this opening, Trump continues with the following statement: »Nobody likes a loser [...]. Yet, here we stand today, the greatest superpower on Earth, and everyone is eating our lunch. That's not winning « (Trump 2016a, 1). Throughout the book, Trump caters to doomsday images that emphasize the graveness of the situation and call for immediate action ${ }^{25}$; this becomes most obvious in the book's final passages: »We are at a critical turning point in our history [...]. America may be struggling, it may be crippled, but we can rise again « (Trump 2016a, p. 169). In Great Again as well as in televised debates with other Republican candidates, Trump has frequently evoked an apocalyptic scenario in which the >bad guys $<$ should be expelled from the American homeland and/or from the government. Here, Trump taps into a cataclysmic imaginary: With respect to the state of the nation, the stakes are so high that almost every action seems justified to clean out these Augian stables. By the same token, Trump routinely warned against $>$ riots, $<$ should he be damaged or removed as a leader (cf. Reuters 2016). ${ }^{26}$

The common chant during Trump rallies, »Build the Wall, « is the quintessence of this apocalyptic imagination (see Leary 2017, p. 146). In order to avoid unhinged chaos, >revolutionary change $<$ is needed to fulfill the aims of the American Founding Fathers. Such public stagings of $>$ the American nation in crisis $<$ and the ensuing calls for a dauntless savior are filled with drama, both in the vocabulary used by Trump and his followers and the messianic dramaturgy of such events. This tendency towards dramatization has not gone unnoticed by the press. »Everything is drama in the New White House - thus Bakari Sellers, Democratic strategist and commentator

\footnotetext{
23 This penchant for apocalyptic scenarios, Martha C. Nussbaum aptly observes, is also employed by the political left. A progressive young and intellectual generation often tends to »demonize an entire half of the American electorate, portraying them as monsters, enemies of everything good. As in the book of Revelation, these are the last days, when a righteous remnant must contend against Satanic forces« (Nussbaum 2018, p. 3).

24 Notably, Trump has often denounced what he calls >globalism< during his campaign and his presidency, championing the concept of >nationalism< instead. Despite (or maybe because) of the term's problematic baggage, Trump has insisted on the positive connotations of concepts such as >nationalist< (as compared to the socially more accepted term $>$ patriotic $<$ ) (see Borger 2019).

25 Trump's apocalyptic imagery is marked by drastic vocabulary that suggests that America is going »from crisis to crisis« (Trump 2016a, p. 79), driven by »a terrible cycle« (Trump 2016a, p. 140). While Trump's attacks are mainly directed against Obama (»an awful president« Trump 2016a, p. 132) and his administration (»has forgotten [...] our heroes « Trump 2016a, p. 47), they also aim at the >dishonest< press and especially »these so-called journalists [...] who flat-out lie« (Trump 2016a, p. 10). Typical of this apocalyptic rhetoric is that it often ends on a promise of salvation, a kind of redemption during which the horrors of the past are undone and replaced by a paradisal future that will save the country: »The one thing you can be certain about is that, unlike the Obama administration, I stand up for this country, proudly and loudly. I continue to be exactly what I have been - the greatest cheerleader for America - the America that won rather than constantly lost « (Trump 2016a, p. 135).
}

26 Notably, coverage of Trump's campaign often also assumed an apocalyptic quality, for example, when his impending presidency was likened to a >Second Civil War $<$ (cf. Delaney/Carter 2016). 
on CNN, described the political situation under Trump in April of 2017 (State of the Union 2017). In a similar vein, Tara Setmayer, a Republican analyst and political observer, remarked on Trump's performance: »We've been living in the theater of the absurd for quite some time now with Donald Trump« (Anderson Cooper 360 Degrees 2018).

Trump needs this sense of melodrama in order to bring to mind the urgency of his political agenda. In the first two and a half years of his administration, the president has signed roughly 114 executive orders - more than any other U.S. president since World War II. Trump's apocalyptic rhetoric is a radical version of the traditional $>$ Us versus Them < pattern. The media seem »fake « or simply »the enemy of the people« (Trump qtd. in: Smith 2019), politicians are depicted as corrupt (unless they agree with Trump's politics), and elections are »rigged « (unless they are won by the right person) (Trump 2016b). This kind of antagonistic rhetoric is deeply ingrained into a cataclysmic discourse that emphasizes the extraordinary and elevates the state of exception to a permanent frame of reference.

In this imagery, social and political practice are characterized by constant battle and existential threat from interior and exterior forces. This doom-filled scenario is eerily reminiscent of Giorgio Agamben's description of the »fictitious state of exception $\ll-$ a kind of »fancied emergency $«-$ that seemed to permeate U.S. cultural politics after 9/11 (Agamben 2003, p. 3). Under the USA Patriot Act, ratified in October 2001, America saw a series of forceful detentions designed to maintain the illusion of national security (cf. Jurecic 2016). Following Agamben's model, this invocation of a constant crisis can be equally applied to the Trump discourse which, in its emotional exceptionalism, is dependent on the specter of the apocalypse to be able to legitimate its radical politics.

\section{Conclusion}

With Donald Trump, the »master seducer« (Hume 2016), American society currently experiences a new quality of political drama. Trump's election campaign as well as his presidency seem marked by a spectacle character that has taken previous populist discourses to another level of representation, that of the entertainment discourse and the social media. This has helped adapt traditional populist strategies - the glorification of the >common man, < the summoning of threatening specters as >enemies of the people, $<$ a fear-mongering anti-establishment rhetoric, and the usage of apocalyptic imagery - to the necessities of contemporary cultural practice and its technological affordances. When analyzing the colorful populist techniques of the Trumpist rhetoric, Guy Debord comes to mind who describes the mechanisms that become effective in the political appropriation of the spectacle as follows: »By means of the spectacle the ruling order discourses endlessly upon itself in an uninterrupted monologue of self-praise. The spectacle is the self-portrait of power in the age of power's totalitarian rule over the conditions of existence « (Debord 1997, p. 19).

It has been discussed by journalists and academics if Trump's MAGA campaign and his presidency are perhaps a sign of the times, signifying a broader tendency 
towards populist strategies in political practice. Both Bernie Sanders and Elizabeth Warren have been connected to populist movements (Kazin 2016; Cantrell 2019). While Trumpism harnesses four key tactics typical of traditional populism (antiestablishment rhetoric, patriotism, nativist imagery, apocalyptic metaphors), his opponents stand in contrast to Trump in most accounts (only resembling Trump in terms of his criticism of the political elite). ${ }^{27}$ Trump also distinguishes himself from most rivals by a celebration of what Brian L. Ott, in his article on Trump's effective employment of Twitter, has called a »politics of debasement« (Ott 2017, p. 59), namely his usage of humiliation and degradation as political tools.

Most importantly, the Trump discourse emulates key elements of entertainment culture, especially from reality television, in its emphasis on dramatization, emotional effect, and spectacle. More than any of his contenders in U.S. politics, Trump plays the whole gamut of the media spectacle, turning his appearances in the public limelight into performances that, while perhaps blunt and loaded with pathos, seem >entertaining, $<$ measured by the standards of commercial television. >Trump the Reality Show< capitalizes upon a number of stratagems that have been successfully tested in the realm of showbiz. In this respect, Trump's populism is also symptomatic of the idiosyncrasies and representational modes of the modern age, including its tendencies towards social backlash. »[E]very major >populist< insurgency, « Michael Kazin notes, »is a warning about serious problems festering in our politics. To simply blame the messenger is an exercise in denial« (Kazin 2016).

Funding Open access funding provided by University of Graz.

Open Access This article is licensed under a Creative Commons Attribution 4.0 International License, which permits use, sharing, adaptation, distribution and reproduction in any medium or format, as long as you give appropriate credit to the original author(s) and the source, provide a link to the Creative Commons licence, and indicate if changes were made. The images or other third party material in this article are included in the article's Creative Commons licence, unless indicated otherwise in a credit line to the material. If material is not included in the article's Creative Commons licence and your intended use is not permitted by statutory regulation or exceeds the permitted use, you will need to obtain permission directly from the copyright holder. To view a copy of this licence, visit http://creativecommons.org/licenses/by/4. $0 /$.

\section{References}

Agamben, Giorgio (2003): State of Exception. Trans. Kevin Attell. Chicago/London.

Anderson Cooper 360 Degrees (2018, March 5). CNN. http://transcripts.cnn.com/TRANSCRIPTS/1803/ 05/acd.02.html (accessed 4 Oct. 2019).

Associated Press (2019, Sept. 9): »Your Way of Life is Under Assault, « Trump Says at Fiery GOP Rally. https://www.marketwatch.com/story/your-way-of-life-is-under-assault-trump-says-at-fierygop-rally-2019-09-09 (accessed Oct. 1, 2019).

Attridge, Derek (2004): The Singularity of Literature. New York/London.

Bessire, Lucas/Bond, David (2017): Introduction: The Rise of Trumpism. https://culanth.org/fieldsights/ introduction-the-rise- of-trumpism?token=260 (accessed 20 July 2019).

Bond, Gary D./Holman, Rebecka D./Eggert, Jamie-Ann L. et al. (2017): >Lyin’ Ted, ২>Crooked Hillary, and >Deceptive Donald $<$ : Language of Lies in the 2016 US Presidential Debates. In: Applied Cognitive Psychology 31, pp. 668-677.

27 Sanders, for example, employs a strong anti-establishment rhetoric, but presents his political agenda as cosmopolitan (not nativist), anti-authoritarian (rather than focused on strong leader figures) and only moderately patriotic (instead of nationalistic). 
Borger, Julian (2019, Sept. 24): Donald Trump Denounces >Globalism< in Nationalist Address to UN. In: The Guardian. https://www.theguardian.com/us-news/2019/sep/24/donald-trump-un-addressdenounces-globalism (accessed 30 Sept. 2019).

Boucher, Ashley (2019, July 11): Arnold Schwarzenegger Claps Back After Donald Trump Digs at Him Over Celebrity Apprentice Ratings. In: People magazine. https://people.com/politics/arnoldschwarzenegger-responds-donald-trump-saying-died/ (accessed 15 Sept. 2019).

Boydston, Jeanne/ Cullather, Nick / Lewis, Jan Ellen et al. (eds.) (2002): Making the Nation. The United States and Its People. Vol. Two. Upper Saddle River, NJ.

Cantrell, Greg (2019, July 30): When We Hear Populism, We Think Donald Trump. But We Should Be Thinking Elizabeth Warren. https://www.washingtonpost.com/outlook/2019/07/30/when-we-hearpopulism-we-think-donald-trump-we-should-be-thinking-elizabeth-warren/ (accessed 14 Aug. 2019).

CBS News (2016, Sept. 10): Hillary Clinton Says Half of Trump's Supporters Are in a >Basket of Deplorables. https://www.youtube.com/watch?v=PCHJVE9trSM (accessed 20 May 2019).

Chicago Tribune (2016, July 21): Donald Trump Says America Is in Crisis - And He'll Fix It >Fast $<$. http:// www.chicagotribune.com/news/nationworld/ct-donald-trump-rnc-20160721-story.html (accessed 18 Sept. 2019).

Chomsky, Noam (1965): Aspects of the Theory of Syntax. Cambridge, Mass.

Debord, Guy (1997): The Society of the Spectacle. [1967]. Trans. Donald Nicholson-Smith. New York.

Delaney, Arthur/Carter, Zach (2016, March 26): Donald Trump and America's >Second Civil War $<$. http:// www.huffingtonpost.com/entry/trump-fascist_us_56f4476de4b0143a9b47bd2e (accessed 26 Apr. 2019).

Elving, Ron (2019, July 19): With Latest Nativist Rhetoric, Trump Takes America Back to Where It Came From. In: npr. https://www.npr.org/2019/07/16/742000247/with-latest-nativist-rhetorictrump-takes-america-back-to-where-it-came-from (accessed 3 Oct. 2019).

Emery, David (2018, Feb. 9): Was >America First< a Slogan of the Ku Klux Klan? In: Snopes. https://www. snopes.com/fact-check/america-first-ku-klux-klan-slogan/ (accessed 22 May 2019).

Garrison, Ben (2017): What Is the Deep State Monster?. https://grrrgraphics.com/product/drain-the-deepstate (accessed 15 June 2019).

God TV (2016, Nov. 3): Televangelist Jack Van Impe Vehemently Supports Donald Trump. https://www. youtube.com/watch?v=ZnRiNZXhIgw (accessed 17 Aug. 2019).

Gomez, Henry J. (2019, Sept. 23): Pete Buttigieg Has Some Thoughts About Ideology — Even If He Rejects Your Labels. In: BuzzFeed News. https://www.buzzfeednews.com/article/henrygomez/petebuttigieg-moderate-populist-bus-tour (accessed 27 Sept. 2019).

Griswold, Alex (2016, May 23): Pro-Trump Evangelical: He Must Be a Christian Because He Points at the Sky a Lot. http://www.mediaite.com/election-2016/pro-trump-evangelical-he-must-be-a-christianbecause-he-points-at-the-sky-a-lot/ (accessed 26 Apr. 2017).

Gusterson, Hugh (2017, Apr. 27): From Brexit to Trump: Anthropology and the Rise of Nationalist Populism. In: American Ethnologist - Journals of the American Ethnological Society. https:// anthrosource.onlinelibrary.wiley.com/doi/full/10.1111/amet.12469 (accessed 12 Sept. 2019).

Halliday, Michael (1978): Language as Social Semiotic: The Social Interpretation of Language and Meaning. London.

Holmes, Su/Jermyn, Deborah (2004): Introduction: Understanding Reality TV. In: Su Holmes/Deborah Jermyn (eds.): Understanding Reality Television. London et al., pp. 1-32.

Hughey, Matthew W. (2017): Bad Hombres? The Implicit and Explicit Racialization of Immigration. In: Humanity \& Society 4.1, pp. 127-129.

Hume, Virginia (2016, April 1): Donald Trump, Master Seducer. In: National Review. https://www. nationalreview.com/2016/04/donald-trump-art-seduction/ (accessed 4 Oct. 2019).

Inglehart, Ronald F./ Norris, Pippa (2016): Trump, Brexit, and the Rise of Populism: Economic Have-Nots and Cultural Backlash. Faculty Research Working Paper Series. Cambridge, Mass. https://research. hks.harvard.edu/publications/getFile.aspx?Id=1401 (accessed 22 Sept. 2019).

Jacobson, Louis/Waychoff, Sarah (2017, May 2): What's Up with Donald Trump and Andrew Jackson? In: Politifact. https://www.politifact.com/truth-o-meter/article/2017/may/02/whats-up-with-donaldtrump-andrew-jackson/ (accessed 23 Aug. 2019).

Jurecic, Quinta (2016, Dec. 14): Donald Trump's State of Exception. Online Blog. https://lawfareblog. com/donald-trumps-state-exception (accessed 29 Aug. 2019).

Kazin, Michael (1998): The Populist Persuasion: An American History. Rev. ed. Ithaca, NY. 
Kazin, Michael (2016, March 22): How Can Donald Trump and Bernie Sanders Both Be >Populist<? In: The New York Times Magazine. https://www.nytimes.com/2016/03/27/magazine/how-can-donald-trumpand-bernie-sanders-both-be-populist.html (accessed 2 May 2019).

Kazin, Michael (2017): Donald Trump and American Populism. In: Andis Kudors/Artis Pabriks (eds.): The Rise of Populism: Lessons for the European Union and the United States of America. Riga, pp. 75-86.

Kellner, Douglas (2001): Grand Theft 2000: Media Spectacle and a Stolen Election. Lanham, Md.

Kellner, Douglas (2003): Media Spectacle. London/New York.

Kellner, Douglas (2016): American Nightmare: Donald Trump, Media Spectacle, and Authoritarian Populism. Rotterdam.

Krause-Jensen, Jakob/Keir, Martin (2018): Trickster's Triumph: Donald Trump and the New Spirit of Capitalism. In: Brian Moeran/Timothy de Waal Malefyt (eds.): Magical Capitalism: Enchantment, Spells, and Occult Practices in Contemporary Economies. Cham, Switzerland, pp. 89-113.

Kurtz, Jason (2017, March 1): Van Jones on Trump: >He Became President of the United States in That Moment, Period<. https://edition.cnn.com/2017/03/01/politics/van-jones-trump-congress-speechbecame-the-president-in-that-moment-cnntv/index.html (accessed 23 Aug. 2019).

Leary, John Patrick (2017): Decoding »Build the Wall«: What Liberal Critics Miss. In: NACLA Report on the Americas 49.2, pp. 146-148

Lee, Michael J. (2006): The Populist Chameleon: The People's Party, Huey Long, George Wallace, and the Populist Argumentative Frame. In: Quarterly Journal of Speech 92, pp. 355-378.

Miles, Edwin A. (1978, Fall): The First People's Inaugural - 1829. In: Tennessee Historical Quarterly 37.3, pp. 293-307.

Morgan, Iwan (2019): Make America Great Again: Ronald Reagan and Donald Trump. In: Mara Oliva/ Mark Shanahan (eds.): The Trump Presidency: From Campaign Trail to World Stage. Cham, Switzerland, pp. 59-82.

NBC. The Apprentice. Created by Mark Burnett. Produced by Trump Productions (2004-2015) et al., 2004-2017.

Newman, Omarosa Manigault (2018): Unhinged: An Insider's Account of the Trump White House. London/New York et al.

Nussbaum, Martha C. (2018): The Monarchy of Fear: A Philosopher Looks at Our Political Crisis. New York/London et al.

Ott, Brian L. (2017): The Age of Twitter: Donald J. Trump and the Politics of Debasement. In: Critical Studies in Media Communication 34.1, pp. 59-68.

Pelled, Ayellet/Lukito, Josephine/Boehm, Fred, et al. (2019): >Little Marco,< >Lyin’ Ted, $>$ Crooked Hillary, $<$ and the $>$ Biased $<$ Media: How Trump Used Twitter to Attack and Organize. In: Natalie Jomini Stroud/Shannon McGregor (eds.): Digital Discussions: How Big Data Informs Political Communication. New York et al., pp. 176-196.

Potter, Chris (2016): In Pennsylvania Appearance, Trump Continues Attacks on Clinton. In: Pittsburgh Post-Gazette. 10 Oct. https://www.abqjournal.com/864571/in-pennsylvania-appearance-trumpcontinues-attacks-on-clinton.html (accessed 12 Aug. 2019).

Reddit (2019): NATIVE.AMERICANS. BEWARE OF FOREIGN.INFLUENCE (Know-NothingParty, 1843). https://www.reddit.com/r/PropagandaPosters/comments/818rxe/nativeamericans_beware_of_ foreigninfluence/ (accessed 10 Oct. 2019).

Reuters (2016, March 16): Donald Trump Says There Will Be >Riots < if He Doesn't Get the GOP Nomination. http://fortune.com/2016/03/16/donald-trump-nomination/ (accessed 12 Apr. 2017).

Rolfe, Mark (2016): The Reinvention of Populist Rhetoric in the Digital Age: Insiders \& Outsiders in Democratic Politics. London.

Scott, Peter Dale (2015): The American Deep State: Wall Street, Big Oil, and the Attack on U.S. Democracy. Lanham, New York, et al.

Skocpol, Theda/Williamson, Vanessa (2013): The Tea Party and the Remaking of Republican Conservatism. Oxford, New York, et al.

Smith, David (2019, Sept. 7): >Enemy of the People<: Trump's War on the Media Is a Page from Nixon's Playbook. In: The Guardian. https://www.theguardian.com/us-news/2019/sep/07/donald-trump-waron-the-media-oppo-research (accessed 5 Oct. 2019).

Snyder, Timothy (2018): The Road to Unfreedom. Russia, Europe, America. New York.

State of the Union (2017, April 23). CNN. \#9.17. Moderated by Dana Bash sitting in for Jake Tapper. Guests: John Kelly, Sen. Dick Durpin, Rep. Mark Sanford, Bakari Sellers, et al.

Tracy, Abigail (2018, Sept. 13): »The Department of Justice is a Hydra «: Trump's Witch Hunt Drives the Deep State Underground. In: https:/www.vanityfair.com/news/2018/09/trumps-witch-hunt-drivesthe-deep-state-underground (accessed 25 May 2019). 
Trump, Donald J. (2015, June 16): Presidential Announcement Speech. Full Transcript. https://time.com/ 3923128/donald-trump-announcement-speech/ (accessed 2 Oct. 2019).

Trump, Donald J. (2016a): Great Again: How to Fix Our Crippled America. 2015. Formerly titled Crippled America. New York/London et al.

Trump, Donald J. (2016b, Oct. 15, 5:23 a.m.) (realDonaldTrump): Hillary Clinton Should Have Been Prosecuted and Should Be in Jail. Tweet.

Trump, Donald J. (2016c, Nov. 9): Victory Speech. http://edition.cnn.com/2016/11/09/politics/donaldtrump-victory-speech/ (accessed 22 Aug. 2019).

Trump, Donald J. (2017a, Jan. 20): Inauguration Speech. https://www.theguardian.com/world/2017/jan/ 20/donald-trump-inauguration-speech-full-text (accessed 2 May 2019).

Trump, Donald J. (2017b, Feb. 27): President Trump Honors Fallen Navy Seal - Wife Receives Standing Ovation. Speech at Joint Session of U.S. Congress. https://www.youtube.com/watch?v=PHZYwFgKeM (accessed 29 Sept. 2019).

Wilkinson, Will, et al. (2016, Oct. 9): What We Saw in the Second Debate. In: The New York Times. https:// www.nytimes.com/interactive/projects/cp/opinion/clinton-trump-second-debate-election-2016 (accessed 30 Sept. 2019).

Wolff, Michael (2018): Fire and Fury: Inside the Trump White House. New York.

Woodward, Bob (2019): Fear: Trump in the White House. New York/London et al.

Woodward, Gary C. (1983): Reagan as Roosevelt: The Elasticity of the Pseudo-Populist Appeals. In: Central States Speech Journal 34: pp. 44-58. 